\title{
Total Phenolic Content of Three Samples from the Powdered Stem Bark of Detarium Microcarpum Guill. and Perr. (Fabaceae)
}

\author{
Abubakar Sani* and Ibrahim Hajara \\ Department of Pharmacognosy and Drug Development, Ahmadu Bello University, Zaria
}

Received: September 11, 2017; Published: September 22, 2017

*Corresponding author: Abubakar Sani, Department of Pharmacognosy and Drug Development, Ahmadu Bello University, Zaria; Tel: 08065619861;

E-mail:sanimazab@gmail.com

\begin{abstract}
Preliminary processing of the plant material was done. The stem cuttings were debarked and the barks dried in an open air under shade. The macroscopical examinations were done. The dried plant materials were powdered. Three different samples of the plant extracts/fraction were used in the determination and the UV-Visible Spectrophotometric Analysis method was adopted. Tannic acid was used as the standard. The absorbencies were measured using the Jenway $630 \mathrm{UV}$-visible spectrophotometer at $570 \mathrm{~nm}$ against water: methanol blank. The various absorbance obtained were plotted against the corresponding concentrations to obtain a standard calibration curve.
\end{abstract}

Keywords: Detarium Microcarpum; Absorbance; Calibration-curve; Phenolics; Samples; Spectrophotometer; Tannins

Abbreviations: TF: Tannin Fraction; RF: Residual Fraction; MCE: Methanolic Plant Extract

\section{Introduction}

Detarium. microcarpum Guill and Perr. belongs to the family Fabaceae. It is commonly called Tallow tree in English. The Hausas from northern Nigeria call it Taura. It is a savannah tree, growing up to $9.114 \mathrm{~m}$, with reddish-brown scaly bark; leaves glaucous beneath; flowers cream in dense inflorescences; fruits are edible, branchlets deciduous. It is a plant of the drier savannahs. Leaflets rounded and usually emarginated at apex, oblong-elliptic, 6-12, alternate: calyx in bud densely pubescent outside; inflorescences congested; leaflets thickly coriaceous, usually about $7-11 \mathrm{~cm}$ broad, but sometimes smaller, with numerous translucid gland-dots; fruits sub orbicular and flattened, about $4 \mathrm{~cm}$ in diameter and $2.5 \mathrm{~cm}$ thick, not very fleshy; often forming small abortive or galled fruits [1].

Phenols constitute a very large group of plant secondary metabolites. They are widespread in nature and found in most in classes of natural compounds having aromatic moieties. They range from simple structures with one aromatic ring to highly complex polymeric substances such as tannins and lignin's. They are important constituents of some medicinal plants and in the food industry. They are utilized as coloring agents, flavorings, aromatizes and antioxidants. Phenolic classes of pharmaceutical interest include:
i. Simple phenolic compounds
ii. Tannins
iii. Coumarins and their glycosides
iv. Anthraquinone and their glycosides
v. Naphthoquinones
vi. Flavones and related flavanoid glycosides
vii. Anthocyanidins and anthocyanin
viii. Lignans and Lignin [2] (Figure 1).

\section{Materials and Methods}

\section{Collection and Preparation of Plant Material}

The plant material was collected from the wild in vegetation around the settlements in Giwa local Government Area located in Kaduna State, Nigeria. The collection was done in December $16^{\text {th }}$,2008. About $1 \mathrm{Kg}$ of the stem cuttingswere collected [3]. Another fresh twig comprising all the essential parts used in the identification of plants was collected and taken to the Herbarium unit of the Department of Biological Sciences, Ahmadu Bello 
University, Zaria forauthentication. A voucher number, 900676 was assigned to the plant sample on $17^{\text {th }}$ December, 2008 by the taxonomists in charge. Preliminary processing of the plant material was done. This includes elimination of undesirable materials and contaminants, washing to remove soil, sorting and cutting. The bark was removed from the stem cuttings dried in an open air under shade. This wasthen powdered using mortar and pestle $[2,3]$.<smiles>Oc1ccccc1O</smiles>

(a) Catechol<smiles>Oc1cc(O)cc(O)c1</smiles>

(b) Phloroglucinol<smiles>O=C(O)c1ccccc1O</smiles>

(c) Salicylic acid<smiles>C=CCc1ccc(O)c(OC)c1</smiles><smiles>Oc1ccc(O)cc1</smiles>

(e) Hydroquinone

(d) Eugenol

Figure 1: Some Simple Phenolic Compounds (a-e) [2].

\section{Extraction of Plant Samples}

Firstly, 1000g of the powdered crude drug was defatted using 5 litre of petroleum ether (60-800C). The marc obtained from this was subjected to extraction by cold percolation using 1 litre of $70 \%$ methanol. The filterate obtained was divided into two portions. Tannins were precipitated from one portion using $1 \%$ solution of gelatin containing $10 \% \mathrm{NaCl}$. This was filtered to separate the precipitated tannins and a filtrate is obtained. The tannins were recovered from the residue by adding another 1 liter of $99 \% \mathrm{MeOH}$ to the precipitate obtained and filtered. This dissolves the tannins leaving a residue of gelatin and $\mathrm{NaCl}$. The filterate contains the tannins while the gelatin and the $\mathrm{NaCl}$ remains in the precipitates as the residue (or the marc). The filtrate was concentrated over water bath at a controlled temperature and must not be charred as some phenolics are unstable at certain high temperatures. The resulting extract constitutes the tannin fraction (TF). The filtrate obtained after precipitating the tannins was also concentrated in an evaporating dish over a water bath. This constitutes the Residual Fraction (RF). The second portion of the filterate obtained after defatting was concentrated to obtain the crude extract (MCE) (Figure 2).

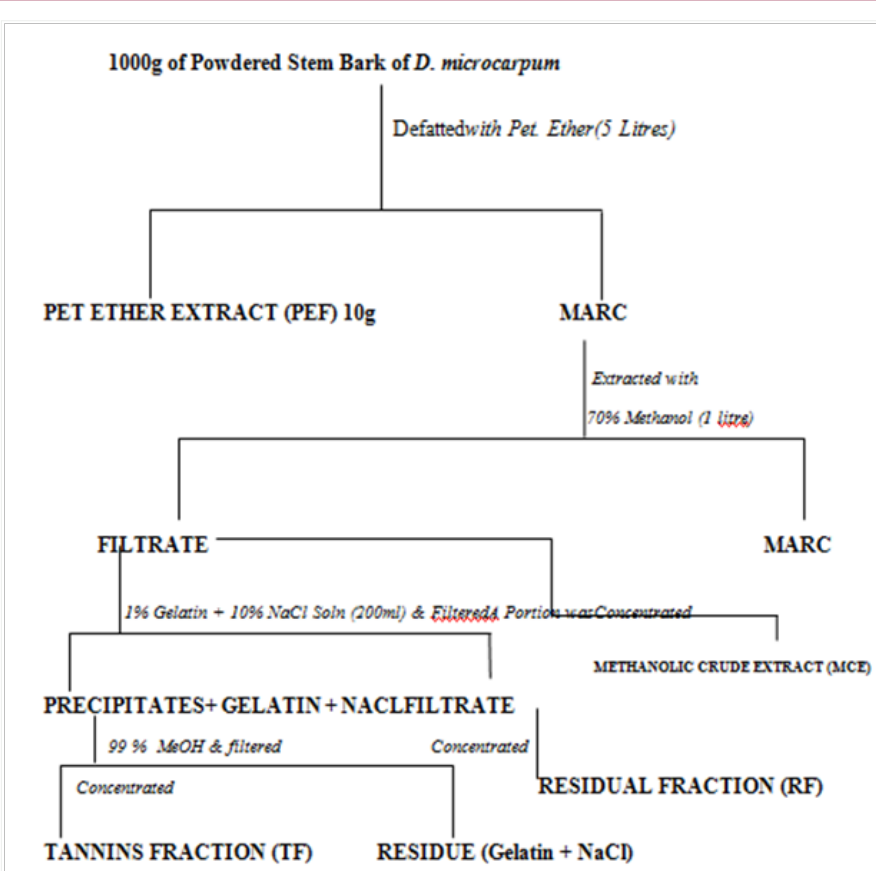

Figure 2: Flow Chart (General Procedure for Preparing Tannin Fraction, Residual Fraction and Crude Extract) [4]. 


\section{Determination of Total Phenolics}

The total phenolics of the stem bark of D. microcapum were determined by the UV-Visible Spectrophotometric Analysis method. Here, tannic acid was used as the standard or reference. Five different concentrations of the tannic acid (4, 8, 12, 16 and 20) $\mathrm{g} / \mathrm{dm}^{3}$ were prepared. Each was then reacted with a few drops of $1 \% \mathrm{FeCl}_{3}$ solution in $50 \%$ Methanol at a $\mathrm{pH}$ of 7.12 . The reaction mixture was allowed to stay at room temperature for about 8-10 minutes after which the absorbencies were measured using the Jenway 630 UV-visible spectrophotometer at 570nm against water: methanol blank. The various absorbance obtained were plotted against the corresponding concentrations to obtain a standard calibration curve. Thereafter, the plant sample was treated in the same way as the tannic acid $[4,5]$.

A standard calibration curve of absorbencies against tannic acid concentrations $\left(4-20 \mathrm{~g} / \mathrm{dm}^{3}\right)$ was plotted so as to determine the corresponding concentrations of the plant samples to be used in the determination procedure (Table 1).

Table 1: Concentrations and Absorbance of the Stem Bark of D. microcarpum.

\begin{tabular}{|c|c|c|c|}
\hline \multicolumn{3}{|c|}{ Concentrations } & \multirow{2}{*}{$\begin{array}{c}\text { Absorbance } \\
\text { (nm) }\end{array}$} \\
\hline$\left(\mathrm{g} / 50 \mathrm{~cm}^{3}\right)$ & $\left(\mathrm{g} / \mathrm{dm}^{3}\right)$ & Molar (M) & \\
\hline 0.2 & 4 & 0.0024 & 0.556 \\
\hline 0.4 & 8 & 0.0047 & 0.603 \\
\hline 0.6 & 12 & 0.0071 & 0.494 \\
\hline 0.8 & 16 & 0.0094 & 0.669 \\
\hline 1.0 & 20 & 0.0118 & 1.585 \\
\hline
\end{tabular}

The total phenolic compounds were calculated by the following formula $\mathrm{T}=\mathrm{CVM}$

Where, $\mathrm{T}=$ Total content of phenolic compounds in TAE/g

$\mathrm{C}=$ Concentration of Extract established from the calibration curve in $\mathrm{g} / \mathrm{dm} 3$

\section{$\mathrm{V}=$ Volume of extract in $\mathrm{ml}$}

\section{$\mathrm{M}=$ Weight of plant extract in grams}

The results were expressed as mg of tannic acid equivalents (TAE)/1g of extract weight.

\section{Results and Discussion}

Yields of Plant Extract and Fractions: From the 1000g of the powdered plant sample, the extract and various fractions had the following yields: the petroleum ether faction (8.6\%), Methanolic Crude Extract (41.2\%), tannin fraction (10.4\%), and the residual fraction (6.5\%). The residue and other substances left after the extraction and fractionation processes makes up the remaining $33.3 \%$ (Table 2). The graph was used to determine the values of $x$ (concentrations) from the values of $y$ (absorbance) measured from the UV-VIS Spectrophometer (Figure 3). The $\mathrm{R}^{2}$ value being up to 0.5 is an indication that there is a strong relationship between the absorbance and the concentrations. This means that the absorbance vary with change in concentration or is dependent on the change in concentration. The crude methanolic plant extract (MCE) gave an absorbance of $1 \mathrm{~nm}$, tannin fraction (TF) had $0.87 \mathrm{~nm}$ and the residual fraction (RF) had $0.44 \mathrm{~nm}$ while the total phenolics were $16 \mathrm{mg}$ TAE/g, $15.86 \mathrm{mg}$ TAE/g and $0.14 \mathrm{mg}$ TAE/g respectively (Table 3).

Table 2: Yields of the Extract and Fractions.

\begin{tabular}{|l|l|l|}
\hline Plant Samples & $\begin{array}{l}\text { Yield of Concentrated } \\
\text { Sample (g) }\end{array}$ & Percentage Yield (\%) \\
\hline $\begin{array}{l}\text { Pet ether Fraction } \\
\text { (PEF) }\end{array}$ & 86 & 8.6 \\
\hline $\begin{array}{l}\text { Methanolic Crude } \\
\text { Extract (MCE) }\end{array}$ & 412 & 41.2 \\
\hline Tannin Fraction (TF) & 104 & 10.4 \\
\hline Residual Fraction (RF) & 65 & 6.5 \\
\hline TOTAL & 667 & 66.7 \\
\hline
\end{tabular}

Table 3: Total Phenolics of the three Samples from Powdered Stem Bark of D. microcarpum.

\begin{tabular}{|c|c|c|}
\hline Extract/Fractions & $\begin{array}{c}\text { The Absorbances } \\
\text { (nm) }\end{array}$ & $\begin{array}{c}\text { Total Phenolics } \\
\text { (mgTAE/g) }\end{array}$ \\
\hline Crude Plant Extract & 1.00 & 16.00 \\
\hline Tannin Fraction & 0.87 & 09.86 \\
\hline Residual Fraction & 0.44 & 06.14 \\
\hline
\end{tabular}

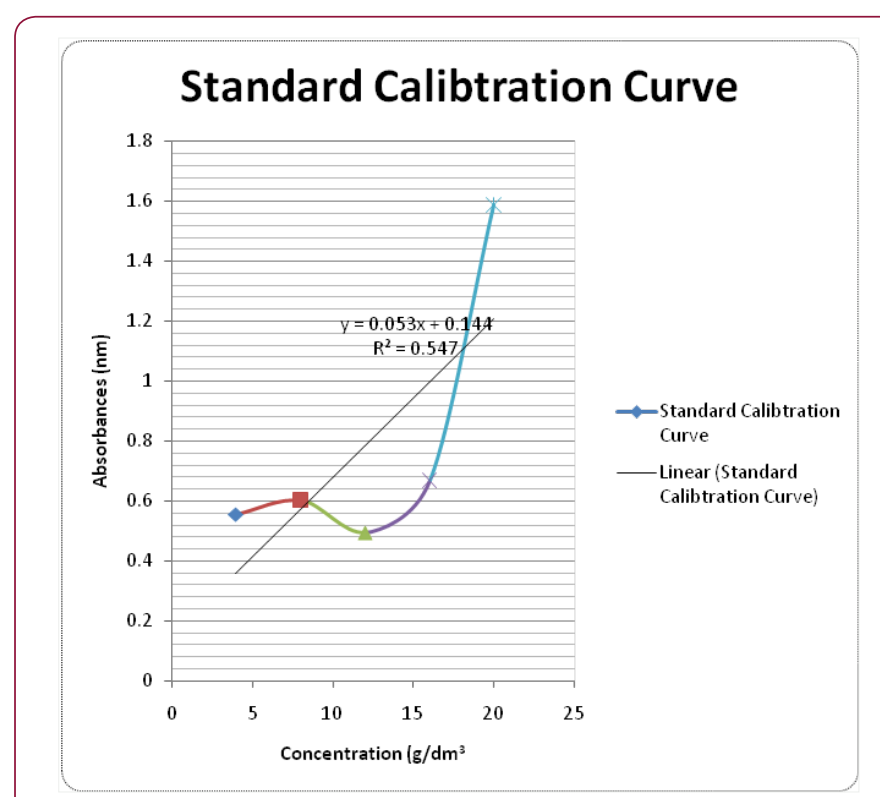

Figure 3: Graph of Absorbance against Concentration of the Samples.

\section{Conclusion}

These total phenolics as determined in terms of Tannic-Acid Equivalence (TAE) are expressed as 16mg TAE/g of crude extract weight, $09.86 \mathrm{mg} \mathrm{TAE} / \mathrm{g}$ of tannin fraction weight and $6.14 \mathrm{mg}$ TAE/g of residual fraction weight. This shows that the crude plant extract still has the highest phenolic content although only slightly different from the ones in the tannin fraction. The residual fraction has the least content of the phenolics. This obviously constitutes other phenolics apart from the tannins since the tannins have been separated from this fraction. This also indicates that amongst the 
other phenolic compounds, Detarium microcarpumis richest in tannins as compared to its content of other phenolic compounds.

\section{Acknowledgement}

Our sincere and profound gratitude goes to Mr. Enyeribe Collins and Mr. Jerry Akawu both of Nigerian Institute of Leather and Science Technology (NILEST), Samaru, Zaria who guided immensely with the determination of the total phenolic content of the plant samples. Thank you very much.

\section{References}

1. Hutchinson J, Daziel JN (1966) Flora of Tropical West Africa. First Edition, Crown Agents for Overseas Government and Administrations, Millbank, London, England, pp. 457.
2. Evans WC (2008) Trease and Evans pharmacognosy. 15th Edition Rajkamal Electric press, Delhi, India, pp. 516-536.

3. Birdi TJ, Brijesh S, Daswani PG (2006) Approaches Towards the Preclinical Testing and Standardization of Medicinal Plants. Foundation for Medical research, India.

4. Canell, Richard JP (1998) Natural Products Isolation Glaxo Welcome Research and Development, Stevenage, Herts, Humana Press Totowa, New Jersey, USA, pp 349-352.

5. Singleton VL, Orthofer R, Lamuela Raventos RM (1999) Analysis of total phenols and otheroxidation substrates and antioxidants by means of Folin-Ciocalteu Reagent. Methods Enzymol 299: 152-178.

\begin{tabular}{ll}
$\begin{array}{l}\text { BIOMEDICAL } \\
\text { RESEARCHES }\end{array}$ & Assets of Publishing with us \\
& - Global archiving of articles \\
\hline & - Immediate, unrestricted online access \\
\hline
\end{tabular}

